\title{
Weaning performance of beef Hungarian Fleckvieh calves: 3. Genotype $\times$ environment interaction
}

\author{
ATTILA FÖRDŐS, IMRE FÜLLER, SZABOLCS BENE and FERENC SZABÓ \\ University of Pannonia, Georgikon Faculty, Keszthely, Hungary
}

\section{Abstract}

The interaction of sire and population in Hungarian Fleckvieh beef cattle breed were examined in this study on data from the Hungarian Fleckvieh Breeders Association. Data of 2345 progeny (1 260 male and 1085 female), born between 1992 and 2003, of 35 sires from two populations were evaluated. Preweaning daily gain (PDG) and 205-day weight (205-dw) were analysed. Population, age of cows, year of birth, season of birth and sex of calves as fixed, sire and sire $\times$ population were treated as a random effect. Among the same performance data in the two populations $(A, B)$ genetic correlation $\left(r_{g}\right)$, while by the gradiation of sires rank correlation $\left(r_{\text {rank }}\right)$, were evaluated. Data were analysed with HARVEY'S (1990) Least Square Maximum Likelihood Computer Program and SPSS 9.0 for Windows. Results were as follows: $r_{g}=P B_{A}-P D G_{B}: 0.31_{(P<0.01)} ; 205-d w_{A}-205-d w_{B}: 0.22_{(P<0.01)}$ and $r_{\text {rank }}=P D G:-0.04_{(P>0.05)} ; 205-d w: 0.078_{(P>0.05)}$. According to the result of examination important and significant $(P<0.001)$ sire $\times$ population interaction were found in case of the two traits in Hungarian Fleckvieh breed.

Keywords: beef cattle, sire $\times$ population interaction, genetic correlation, rank correlation, Hungarian Fleckvieh

\section{Zusammenfassung}

\section{Absetzergebnisse ungarischer Fleckviehkälber:}

\section{Genotyp-Umwelt Interaktion}

Am Beispiel der Merkmale »tägliche Zunahme bis zum Absetzen« (PDG) und »205-Tage Gewicht« (205-dw) wurde die Vater/Betrieb-Wechselwirkung bei 2345 (1 260 männlichen und 1085 weiblichen) ungarischen Fleckviehkälbern untersucht, die aus zwei Betrieben von 35 Vätern aus den Jahren 1992 bis 2003 abstammten. Als fixe Effekte wurden Betrieb, Abkalbungsalter der Kühe, Jahr und Jahreszeit der Geburt sowie das Geschlecht und als zufällige Effekte (random) der Vater und die Wechselwirkung Vater/Betrieb betrachtet. In den zwei Betrieben $(A, B)$ wurden genetische Korrelationen $\left(r_{g}\right)$ sowie Rangkorrelationen $\left(r_{\text {rang }}\right)$ berechnet. Für die Berechnungen konnte das HARVEY'S (1990) Least Square Maximum Likelihood Computerprogramm genutzt werden. Die sämtlich signifikanten Ergebnisse waren folgende: $r_{g}=P G_{A}-P D G_{B}: 0,31_{(P<0,01)} ; 205-d w_{A}-205-d w_{B}: 0,22_{(P<0,01)}$ und $r_{\text {rank }}=P D G:-0,04_{(P>0,05)}$ bzw. 205-dw: 0,078 $(P>0,05)$. Bei beiden untersuchten Merkmalen wurde eine bedeutende signifikante Vater/Betrieb-Wechselwirkung $(P<0,001)$ nachgewiesen.

Schlüsselwörter: Fleischrind, Vater/Betrieb-Wechselwirkung, genetische Korrelation, Rangkorrelation, Ungarisches Fleckvieh 


\section{Introduction}

In the former publications of this series of articles was reported about factors, which have an influence on the weaning performance of Hungarian Fleckvieh calves, about population-genetic parameters of the weaning traits and the estimated breeding value. In this work the experiences will be showed which were obtained in the examinations of genotype $\times$ environment interaction, appearing in weaning performances.

It is well-known for a long time that the traits of different populations, which can be measured phenotypically, not always change in the same way owing to the effect of the different environmental factors (WILSON 1974). It was proved by the result of researches that the different genotypes can react upon the different environmental factors in different way, too. It means that the animals with different genetic construction can react upon to the environmental factors in different way or the animals with the same genotype show different phenotypic value under different environmental conditions (HORN and DOHY 1970). The genotype $\times$ environment interaction can have several occurrences. DICKERSON (1962) mentioned some environmental factors, which can have different influences on the performances of populations with different genotype and can cause an interaction. For the examination of genetic $\times$ environmental interactions, for the estimation of interaction component can applied a two- or more-factor variance analysis (HORN 1978). FALCONER (1952) suggested determining the interactions in the different environments with the genetic correlations between the results of the production because any traits measured in two different environments can be treated from genetic point of view as two different traits (FALCONER and MACKAY 1996). If the estimated genetic correlation is close, the rank-line of the estimated breeding animals will be unrelated to the environment, whereas the loose genetic correlation or the total independence of traits means that the rank-line of the examined breeding animals evaluated in two different environments can considerably differ from each other. By calculation of rank-correlation coefficient informing data can be obtained referring to the type of genotype $\times$ environment interaction, where there are differences in the rank-line, which was built up according to the mean performances of the examined genotypes (HORN 1978). VOSTRY et al. (2009) found six Czech beef cattle races for weaning weight that environment interaction was not biologically important and can be ignored in the evaluation of beef cattle in the Czech Republic.

Several researchers examined the effect of different environmental factors and interactions (MÜLLER 1991, NOTTER et al. 1992, SOTO-MURILLO et al. 1993, KOVÁCS et al. 1993, MORRIS et al. 1993, SANFTLEBEN et al. 1994, MATHUR et al. 1995, TŐZSÉR et al. 1996, DE MATTOS et al. 2000, FERREIRA et al. 2001, SANDELIN et al. 2002, LENGYEL et al. 2003ab, DE SOUZA et al. 2003, IBI et al. 2005, SZABÓ et al. 2006). The above mentioned examinations expressly show the importance of genotype $x$ environment interactions.

The aim of this work was to estimate the weaning performances of Hungarian Fleckvieh calves in a way, which wasn't applied so far and to obtain newer data about the performance of Hungarian Fleckvieh bulls in different environments, about the breeding value and the genotype $\times$ environment (sire $\times$ population) interaction. 


\section{Material and methods}

The examinations were made on the database given by the Association of Hungarian Fleckvieh Breeders. In the evaluation the data of 2345 calves ( 1260 bulls and 1085 heifers) born between 1992 and 2003 in two populations were used. The examined traits were the preweaning daily gain (PDG) and the 205-day weight (205-dw). From the evaluated factors age of cows at calving, year of birth and sex were treated as fixed effects, the sire and the sire $\times$ population interaction as random effects. The age of calves - from the birth to the weaning - was a covariant factor in case of preweaning daily gain. The Table 1 shows the models applied for the estimation of the effects of the several traits.

The database included the data of calves descending from 35 breeding bulls in two populations - population A and population B. Each bull had calves in both populations.

Table 1

The statistical models

Die statistischen Modelle

\begin{tabular}{|c|c|c|c|}
\hline Source of variance & Classes & Preweaning daily gain g/day & 205-day weight kg \\
\hline Sire & 35 & + & + \\
\hline Population & 2 & + & + \\
\hline Age of cows & 15 & $* * * *$ & $* * * *$ \\
\hline Year & 12 & $* * * *$ & $* * * *$ \\
\hline Season & 4 & $* * * *$ & $* * * *$ \\
\hline Sex & 2 & $* * * *$ & $* * * *$ \\
\hline Sire $\times$ population interaction & 70 & $* * * *$ & $* * * *$ \\
\hline Covariant (age of calves at weaning)b1 & - & $* * * *$ & - \\
\hline Residual & - & + & + \\
\hline
\end{tabular}

${ }^{*} P<0.1, \quad{ }^{*} P<0.05, \quad{ }^{* * *} P<0.01, \quad{ }^{* * *} P<0.001, \quad{ }^{*}$ part of the model, but significant level should not be calculated, - the model doesn't include this effect

The general form of the model applied for the preweaning daily gain is as follows:

$$
\hat{Y}_{i j k l m n o}=\mu+S_{i}+H_{j}+S H_{i j}+Y_{k}+E_{l}+C_{m}+I_{n}+b\left(x_{i j k l m n o}-X\right)+e_{i j k l m n o}
$$

where $\hat{Y}_{i j k l m n o}$ is the weaning weight and gain/life day of the calf, whose age is 0 , sex is $n$, from the sire $i$, whose age is $k$, in the population $j$, in the season $I$, from a cow whose age is $m ; \mu$ is the mean value of all observations, $E_{l}$ is the fixed effect of the season of birth, $S_{i}$ is the random effect of sire, $C_{m}$ is the fixed effect of age of cow at calving, $H_{j}$ is the fixed effect of population, $I_{n}$ is the fixed effect of sex, $S H_{i j}$ the random effect of sire $\times$ population interaction, $Y_{k}$ is the fixed effect of the year of birth, $b$ is the random effect of the regression coefficient and $e_{i j k l m n o}$ is the random residual.

The method of evaluation of the 205-day weight differs from the former one so far as the age of the calves as covariant wasn't included by the model. The model was following:

$$
\hat{Y}_{i j k l m n o}=\mu+S_{i}+H_{j}+S H_{i j}+Y_{k}+E_{l}+C_{m}+I_{n}+e_{i j k l m n o}
$$

For the estimation of breeding value of bulls sire model was applied. The sire model is a mixed model, which takes into consideration the fixed and the random effects as well. It differs from the animal model so far as it is necessary to know the sire only; the other family relations of the animal aren't needed. The estimation was made by HARVEY'S (1990) Least Square Maximum Likelihood Computer Program. 
The genetic correlations between the herds we calculated among the genetic values of the given trait with the following formula:

$$
r_{g}=\frac{\sigma_{G 1 G 2}}{\sqrt{\sigma_{G 1}^{2} \cdot \sigma_{G 2}^{2}}}
$$

where $r_{g}$ is the genetic correlation, $\sigma_{G 1}^{2}$ is the variance of the given trait in one of the populations, $\sigma_{G 2}^{2}$ is the the variance of the given trait in the other population and $\sigma_{G 1 G 2}$ is the covariance of the two traits.

The rank-line of the breeding bulls we calculated by a rank-correlation coefficient.

Data were arranged with Microsoft Excel XP program while variance analysis resp. rank-correlation coefficient calculation with SPSS 9.0 software.

\section{Results and discussion}

According to the results of the examination - as it can be seen in the Table 1 - the age of cows, year, season, sex, sire $\times$ population interaction and the age at weaning had a significant $(P<0.001)$ influence on the preweaning daily gain and the 205-dw. These results are similar to the results of SZABÓ et al. (2006), LENGYEL et al. (2003b), and TŐZSÉR et al. (1996).

The contribution of examined factors to the total variance is shown by the Table 2. It can be seen that the sire and the population by itself didn't influence both traits, but they together influenced them significantly. In case of 205-dw the greatest effect had the sex (51\%). It is similar to the results of LENGYEL et al. (2003b), and KOVÁCS et al. (1993). In case of the preweaning daily gain the age of cows had the greatest effect $(27.7 \%)$. This value differs from the results of SZABÓ et al. (2006). The interaction component was in case of both traits the fifth most important source of variance, it gave not more than $5.23-3.08 \%$ of the total variance. A significant interaction was observed by MÜLLER (1991), NOTTER et al. (1992), FERREIRA et al. (2001), DE SOUZA et al. (2003), IBI et al. (2005).

Table 2

The contribution of source of variance to total variance, $\%$ Das Verhältnis der Varianzquellen in der Gesamtvarianz, in \%

\begin{tabular}{lcc}
\hline Source of variance & Preweaning daily gain & 205-day weight \\
\hline Age of cows & 27.72 & 18.21 \\
Year & 29.09 & 17.06 \\
Season & 17.22 & 10.12 \\
Sex & 20.71 & 51.50 \\
Sire $\times$ population interaction & 5.23 & 3.09 \\
\hline
\end{tabular}

The Table 3 includes the genetic correlations calculated among the performance data in the two populations. According to ROBERTSON (1959) the genotype $\times$ environment interaction is important, when the genetic correlation between the same traits measured in the different populations is smaller than 0.8 . In the results it can be seen that the genotype $\times$ environment interaction was of great importance in case of both traits, because small $\left(r_{g}=0.22-0.31\right)$ genetic correlation coefficients were obtained. It is in accordance with the results of SOTO-MURILLO et al. (1993), FERREIRA et al. (2001), DE SOUZA et al. (2003). 
Table 3

Genetic correlations $\left(r_{g}\right)$

Genetische Korrelationen $\left(r_{g}\right)$

\begin{tabular}{lcc}
\hline & \multicolumn{2}{c}{ Population B } \\
Population A & Preweaning daily gain & 205-day weight \\
\hline Preweaning daily gain & $0.31^{* * *}$ & - \\
$205-$ day weight & - & $0.22^{* * *}$ \\
\hline${ }^{* * *} P<0.01$ & &
\end{tabular}

The Table 4 shows the breeding value of the evaluated bulls. The Figure shows the rankline of bulls according to the estimated breeding values.

It can be seen in the figure that the sire $\times$ population interaction was so high that it caused change in the rank-line.

Table 4

Breeding value of sires of populations $A$ and $B$

Zuchtwerte der Bullen der Populationen $A$ und $B$

\begin{tabular}{lrrrrrr}
\hline Identity number & \multicolumn{2}{c}{ Number of progeny } & \multicolumn{2}{c}{ Preweaning daily gain, g/day } & \multicolumn{2}{c}{ 205-day weight, kg } \\
of sires & $\mathrm{A}$ & $\mathrm{B}$ & $\mathrm{A}$ & \multicolumn{1}{c}{$\mathrm{B}$} & \multicolumn{1}{c}{$\mathrm{A}$} & \multicolumn{1}{c}{$\mathrm{B}$} \\
\hline 12314 & 56 & 60 & -8.26 & -62.91 & -2.11 & -9.27 \\
12316 & 115 & 145 & 15.26 & 40.05 & 1.94 & 9.38 \\
12637 & 12 & 25 & 21.49 & 35.11 & 2.95 & 5.63 \\
12860 & 22 & 84 & -22.77 & -52.87 & -5.96 & -8.66 \\
12928 & 106 & 62 & 4.38 & 38.87 & -1.06 & 2.86 \\
12930 & 62 & 81 & -103.58 & -22.18 & -20.48 & -6.28 \\
13178 & 16 & 51 & 9.51 & 52.76 & 2.81 & 12.05 \\
13179 & 27 & 24 & -51.06 & 68.10 & -8.62 & 14.24 \\
13832 & 12 & 16.99 & -46.88 & -0.32 & -11.72 \\
13950 & 37 & 12 & -60.81 & -47.58 & -12.99 & -5.90 \\
13951 & 15 & 29 & -37.67 & -23.27 & -6.15 & -4.35 \\
14180 & 14 & 21 & -31.61 & 25.82 & -6.01 & 7.23 \\
14283 & 68 & 31 & 71.89 & 5.68 & 14.44 & 0.83 \\
14459 & 33 & 23 & 16.65 & 7.00 & 2.20 & 0.12 \\
14502 & 21 & 18 & -16.09 & 55.70 & -0.89 & 13.53 \\
14588 & 38 & 10 & 39.44 & 12.69 & 7.84 & 1.40 \\
14595 & 104 & 122 & 28.23 & -29.48 & 1.68 & -4.61 \\
15505 & 43 & 104 & 69.64 & -36.88 & 12.96 & -4.40 \\
15603 & 19 & 60 & -14.00 & 45.78 & 2.00 & 7.88 \\
16466 & 22 & 40 & 18.54 & 15.46 & 6.05 & 2.18 \\
\hline
\end{tabular}

Table 5

Rank correlations

Rangkorrelationen

\begin{tabular}{lcc}
\hline Population & A & B \\
\hline & Rank correlations preweaning daily gain, $r_{\text {rank }}$ \\
A & 1 & $-0.044_{p>0.05}$ \\
B & $-0.044_{P>0.05}$ & 1 \\
& Rank correlations & $205-$ day weight, $r_{\text {rank }}$ \\
A & 1 & $0.078_{p>0.05}$ \\
B & $0.078_{P>0.05}$ & 1 \\
\hline
\end{tabular}


The calculated rank-correlation coefficient (Table 5) was $r_{\text {rank }}=$ PDG: $-0.04 ; 205-d w: 0.07$ and it wasn't significant. It means that you canst draw a conclusion from the measuring of the performance of the genotypes in one environment relating to the direction and nature of changes of performance, which can be expected in the other environment.

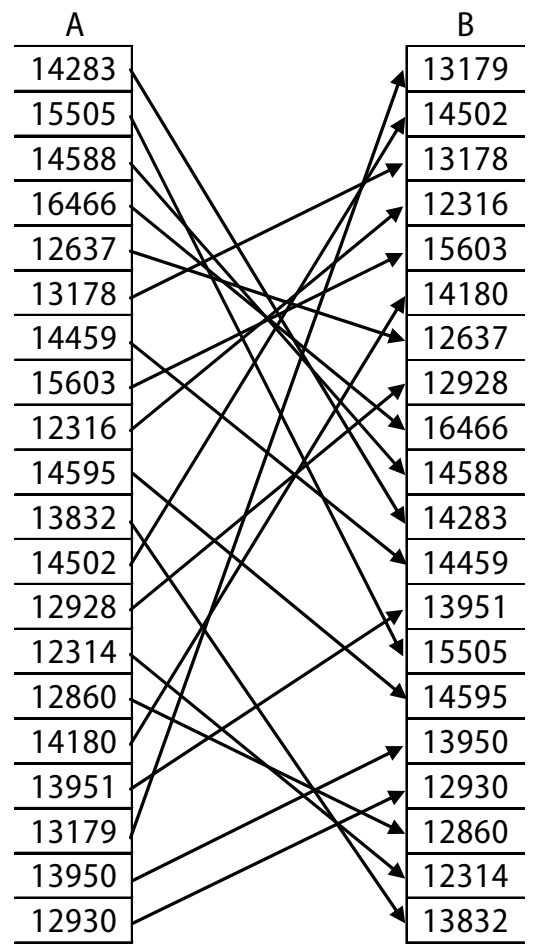

Figure

Reranking of sires by their breeding value for 205-day weaning weight

Änderung der Rangordnung der Bullen in den 205-Tage Gewichten

The results are similar to the statements of MÜLLER (1991) and NOTTER et al. (1992), who found such sire $\times$ population interactions, which caused a change of the rank correlation of breeding bulls in the populations and regions.

Summing up the results it can be stated that an important sire $\times$ population interaction could be found relating to the preweaning daily weight and the 205-day weight in the breed Hungarian Fleckvieh. The genotype $\times$ environment interaction was found so high, that it caused the change of the rank-line of sires according to the weaning performances. This interaction calls the attention that it is to go about carefully in the evaluation of the Hungarian Fleckvieh sires if they aren't used in the same population in which they were ranked. The reliability of evaluation of the breeding value can be lower, if the interactions will be left out of consideration. To eliminate this, the mathematic model of several evaluating methods for the breeding value (e.g. BREEDPLAN) takes the sire $\times$ population interaction in account. 


\section{References}

De Mattos D, Bertrand JK, Misztal I (2000) Investigation of genotype $\times$ environment interactions for weaning weight for Herefords in three countries. J Anim Sci 78, 2121-6

De Souza JC, Gadini CH, Da Silva LOC, Ramos AA, Euclides Filho K, De Alencar MM, Ferraz Filho PB, Van Vleck LD (2003) Estimates of genetic parameters and evaluation of genotype $\times$ environment interaction for weaning weight in Nellore cattle. Arch Latinoam Prod Anim 11, 94-100

Dickerson GE (1962) Implications of genetic-environmental interaction in animal breeding. Anim Prod 4, 47-63

Falconer DS, Mackay TFC (1996) Introduction to Quantitative Genetics. 4th Ed. Longman, London, UK

Falconer DS (1952) The problem of environment and selection. Am Naturalist 86, 293

Ferreira VCP, Penna VM, Bergmann JAG (2001) Genotype environmental interaction in some growth traits of beef cattle in Brazil. Arq Bras Med Vet Zootec 53, 385-92

Horn A, Dohy J (1970) Evaluation and Breeding of Cattle breed of World. Agricultural Publisher, Budapest, Hungary [in Hungarian]

Horn $\mathrm{P}$ (1978) The genotype $\times$ environment interaction. In: Timely problems of applying the genetic in animal breeding. Agricultural Publisher, Budapest, Hungary, 69-73 [in Hungarian]

Ibi T, Hirooka H, Kahi AK, Sasae Y, Sasaki Y (2005) Genotype $\times$ environment interaction effects on carcass traits in Japanese Black cattle. J Anim Sci 83,1503-10

Kovács A, Szűcs E, Völgyi-Csík J (1993) The role of breeding region, season and sex in weaning performances of Limousin calves. Hung J Anim Prod 42, 117-30 [in Hungarian]

Lengyel Z, Domokos Z, Márton D, Erdei I, Wagenhoffer Zs, Szabó F (2003a) Weaning performance of Charolais beef calves in Hungary. 54th Annual Meeting of the EAAP, Roma, Italy 41

Lengyel Z, Komlósi I, Balika S, Major T, Erdei I, Szabó F (2003b) Examination of reproduction and weaning results in Hungarian Limousin population. 1st Paper: Sire model. Hung J Anim Prod 52, 25-38 [in Hungarian]

Mathur PK, Schlote W (1995) Univariate or multivariate approach for estimating genotype-environment interactions? Arch Tierz 38, 577-86

Morris CA, Baker RL, Hickey SM, Johnson DL, Cullen NG, Wilson JA (1933) Evidence of genotype by environment interaction for reproductive and maternal traits in beef cattle. Anim Prod 56, 69-83

Müller J (1991) Genotyp-environment interaction in progeny-test of beef-marked Simmental-sires. Arch Tierz 34, 371-8 [in German]

Notter DR, Tier B, Meyer K (1992) Sire × Herd Interactions for Weaning Weight in Beef Cattle. J Anim Sci 70, 2359-65

Robertson A (1959) The sampling variance of genetic correlation coefficient. Biometrics 15, 469-85

Sandelin BA, Brown AH, Brown MA, Johnson ZB, Kellogg DW, Stelzleni AM (2002) Genotype $\times$ environmental interaction for mature size and rate of maturing for Angus, Brahman, and reciprocalcross cows grazing bermudagrass or endophyte infected fescue. J Anim Sci 80, 3073-6

Sanftleben H, Sanftleben P (1994) Determination of interactions between sire and ration in bull progeny groups of different genotypes. Arch Tierz 37 Special Issue, 179 [in German]

Soto-Murillo HW, Faulkner DB, Gianola D, Cmarik GF (1993) Sire $\times$ pasture program interaction effects on preweaning performance of crossbred beef calves. Liv Prod Sci 33, 67-75

Szabó F, Füller I, Fördős A, Keller K, Nagy B, Nagy L, Bene SZ (2006) Weaning performance of beef Hungarian Fleckvieh calves. 1st Paper: Environmental factors. Hung J Anim Prod 54, 333-42 [in Hungarian]

Tőzsér J, Dobora L, Domokos Z, Kertész I, Zsoltész S (1996) Evaluation of weaning performance of Charolais calves in a stock-breeding. Hung J Anim Prod 45, 349 [in Hungarian]

Vostry L, Pribyl J, Scholte W, Jakubec V, Majzlik I, Mach K (2009) Estimation of animal $\times$ environment interaction in Czech beef cattle. Arch Tierz 52,15-22

Wilson SP (1974) Genotype by environment interaction in the context of animal breeding. 1st World Cong Gen Livest Prod Madrid 1, 393

Received 9 August 2008, accepted 10 December 2009.

Corresponding author:

FERENC SZABÓ

email: szf@georgikon.hu

Georgikon Faculty, University of Pannonia, Deák Ferenc str. 16. Pf. 71, H-8360 Keszthely, Hungary 